\title{
Retrospective analysis of patients with hereditary nonpolyposis colorectal cancer (HNPCC)
}

\author{
Banaszkiewicz Zbigniew ${ }^{*}$ Pawel Jarmocik, Marcin Mrozowski, Arkadiusz Jawien \\ From Annual Conference on Hereditary Cancers 2013 \\ Szczecin, Poland. 26-27 September 2013
}

\begin{abstract}
We performed a one-center cohort retrospective analysis of 1378 non-selected patients operated for colorectal cancer (CRC) in the years $1994-2013$. For the purpose of this study we divided patients into three subdivisions reflecting their family history of HNPCC-associated cancers among first- and second-degree relatives. On detailed pedigree analysis of the families we identified 59 patients as being affected with HNPCC (4.28\%). Compared with other CRC patients our HNPCC subjects were significantly younger at time of diagnosis (median age 51 years, $\mathrm{p}<0.05$ ), were more likely to present with right-sided tumors rather than with rectal ones $(\mathrm{p}<0.05)$. Synchronous tumors were found in 45 CRC patients $(3.27 \%)$, of whom HNPCC subjects were predominant (8.47 vs. $3.03 \%$, $\mathrm{p}=0.02)$. HNPCC patients were also more likely to receive radical resection surgery compared with other CRC patients (93.22\% vs. $86.73 \%)$. Patients with HNPCC presented with more favorable staging and more frequent mucinous component on histological examination. Overall survival was statistically longer in HNPCC than in other CRC patients ( 45 vs. 25 months, $\mathrm{p}=0.01806$ ). Submitted data and our experience in colorectal surgery made us to support conclusion corroborated by literature evidence and regarding fine distinction between HNPCC and sporadic CRC patients.
\end{abstract}

Published: 9 September 2015

doi:10.1186/1897-4287-13-S1-A8

Cite this article as: Zbigniew et al:: Retrospective analysis of patients with hereditary nonpolyposis colorectal cancer (HNPCC). Hereditary

Cancer in Clinical Practice 2015 13(Suppl 1):A8.

\footnotetext{
*Correspondence: banasz@cm.umk.pl

Department of General, Gastrointestinal, Colorectal, and Oncology Surgery,

Department and Clinic of Vascular Surgeryand Angiology, University Hospital 2, Bydgoszcz, Poland
}

(c) 2015 Banaszkiewicz et al. This is an Open Access article distributed under the terms of the Creative Commons Attribution License (http://creativecommons.org/licenses/by/4.0), which permits unrestricted use, distribution, and reproduction in any medium, provided the original work is properly cited. The Creative Commons Public Domain Dedication waiver (http://creativecommons.org/
Submit your next manuscript to BioMed Central and take full advantage of:

- Convenient online submission

- Thorough peer review

- No space constraints or color figure charges

- Immediate publication on acceptance

- Inclusion in PubMed, CAS, Scopus and Google Scholar

- Research which is freely available for redistribution Submit your manuscript at
www.biomedcentral.com/submit Submit your manuscript at publicdomain/zero/1.0/) applies to the data made available in this article, unless otherwise stated.

C Biomed Central 